\title{
Specific resistance factors to yellow rust in seedlings of some French wheat varieties and races of Puccinia striformis Westend in France
}

\author{
C de Vallavieille-Pope 1*, H Picard-Formery ${ }^{1}$, S Radulovic 2,3, R Johnson 2 \\ 1 INRA Laboratoire de Pathologie Végétale, F78850 Thiverval-Grignon, France; \\ 2 IPSR Cambridge Laboratory, Trumpington, Cambridge CB2 2JB, UK; \\ 3 Faculty of Agriculture, Sagrebacka 18, 71000 Sarajevo, Yugoslavia
}

(Received 5 September 1989; accepted 22 December 1989)

\begin{abstract}
Summary - Infection types in Triticum aestivum $L$ seedlings induced by 9 French races of Puccinia striformis Westend were used to assess the hypothetical content of specific genes for resistance to yellow rust in 21 wheat varieties widely grown in France. Resistance to the race OEO showed that none of the varieties lacked resistance factors. Most of the varieties possessed only 1 to 3 known $Y r$ genes. The postulated genes were $Y r 1, \quad Y r 2$, (Yr3a + Yr 4a), Yr6 and Yr7. The varieties Festival, Fidel, Beauchamp, Gala, Castan, Scipion, Caton, Darius, Top, Soissons, and Thésée may carry one or more resistance factors belonging to the set of SD (Strubes Dickkopf), Yr2, and $\left(Y_{r} 3 a+Y_{r} 4 a\right)$. Further hypotheses were developed with the use of British races. Top was postulated to possess $\left(Y_{r} 3 a+Y r 4 a\right)$ and Darius to have $Y r 2 . Y r 7$ was postulated in Prinqual, Talent, and Tango. Corin probably possesses $\operatorname{Yr} 1$ and might also carry $\operatorname{Yr} 2$ and/or $(Y r 3 a+Y r 4 a)$. Garant and Hardi may possess $\operatorname{Yr} 7$ and $\operatorname{Yr} 2$ or $(Y r 3 a+\operatorname{Yr} 4 a)$. Récital and Austerlitz had reactions consistent with the presence of $Y_{r} 6$, and the latter may have an extra gene. Camp Rémy and Arminda were resistant to all races tested. Surveys of $P$ striiformis showed the importance of races whose virulence spectra were able to match most of these resistance genes. Two races (45E140 and $45 \mathrm{E} 172$ ) were mostly responsible for the 1987 and 1988 epidemics; 3 others (41E136, 109E141, and 109E173) were also important.
\end{abstract}

\section{Triticum aestivum L / Puccinia striformis Westend / virulence / Yrgenes}

\begin{abstract}
Résumé - Résistance spécifique à la rouille jaune de variétés françaises de blé tendre au stade plantule et inventaire des races de Puccinia strifformis Westend en France. Les facteurs de résistance spécifique à la rouille jaune ont été recherchés au stade plantule sur 21 variétés de blé tendre parmi les plus cultivées en France. 9 races de Puccinia striiformis Westend d'origine française ont été testées sur la totalité de l'échantillon et 11 races d'origine britannique ont été confrontées à 7 de ces variétés. Une analyse race par race a été préférée à la méthode globale fondée sur la comparaison des différents types d'infection entre d'une part les variétés possédant des facteurs de résistance identifiés et d'autre part celles dont les gènes sont inconnus. Dans le cas présent il est procédé par élimination successive des gènes de résistance qui ne peuvent intervenir du fait de la compatibilité entre une race donnée et les variétés étudiées. Ainsi, l'étude systématique des races de P striiformis en commençant par les plus simples d'entre elles permet d'isoler par déduction les gènes de résistance. Les facteurs identifiés sont SD (Strubes Dickkopf), Yr1, Yr2, (Yr3a + Yr4a), Yr6 et Yr7 (tableau III). Toutes les variétés possèdent au moins un facteur de résistance puisqu'elles résistent à la race avirulente $O E O$ et le nombre de leurs gènes semble limité à 3. Talent, Tango et Prinqual semblent posséder Yr7, Top aurait ( Yr3a + Yr4a), Darius Yr2 et Récital Yr6. Le facteur de résistance possible dans les variétés Festival, Fidel, Gala, Castan est SD, Scipion et Soissons pourraient avoir (Yr3a + Yr4a). Corin possèderait au moins Yr1, Beauchamp et Thésée Yr2, Austerlitz Yr6, et Garant et Hardi Yr7. Enfin, Camp Rémy et Arminda se sont montrées résistantes à toutes les races testées. Cette situation de relative homogénéité vis-à-vis de la résistance spécifique à la rouille jaune s'explique par le manque de prise en compte de ce caractère dans les programmes de sélection. Toutefois, l'introduction de nouveaux facteurs de résistance spécifique ou de nouvelles associations de résistance dans les variétés en voie de sélection n'est envisageable que dans des variétés possédant un bon niveau de résistance générale. En effet, le suivi des races de $\mathrm{P}$ striiformis a montré leur complexité. Les races présentes en 1984 et 1985 dans les pépinières des sélectionneurs étaient virulentes sur Yr1, Yr2, (Yr3a + Yr4a), Yr7 et celles responsables de l'épidémie de 1987 et 1988 portaient les virulences capables de surmonter Yr1, Yr2, (Yr3a+ Yr4a) et Yr6 (45E140, 45E172) et certaines également Yr3b et Yr4b (109E141 et 109E173).
\end{abstract}

Triticum aestivum L / Puccinia striformis Westend / virulence / gènes Yr

\footnotetext{
* Correspondence and reprints
} 


\section{INTRODUCTION}

Puccinia striiformis Westend, an obligate parasite that causes yellow rust in wheat, can be differentiated into races on the basis of interactions with varieties that have specific resistance genes and can evolve to overcome their resistance. The combined use of varietal resistance and fungicides is an advisable means of controlling this disease given the inherent cost of chemical treatment and the possibility of selecting fungal strains resistant to fungicides (Bingham, 1981). Application of this method of control requires observation and analysis of the parasite population and also an understanding of the genetic resistance of the cultivated varieties. This procedure, which has been followed for over 20 years in the Netherlands (IPO, Wageningen) and Great Britain (National Institute of Agricultural Botany and Plant Breeding Institute, Cambridge, UK), has been recently adopted in France. Since 1984, an annual race survey has been carried out using foliar samples taken from the principal wheat-growing regions of France.

It is possible to recognize 2 types of specific resistance to yellow rust (Zadoks, 1961). The first type is evident at the seedling stage and lasts for the life of the host plant. In Western Europe, 14 factors producing this type of overall resistance have been identified to date (Johnson et al, 1972; Röbbelen and Sharp, 1978; Stubbs, 1985). Ten of these factors have been genetically analyzed and are designated as genes $Y r 1$ to $\operatorname{Yr} 10$ (McIntosh, 1983). Yr1, Yr2, Yr5, Yr7, and Yr8 are single, usually dominant genes, and $Y r 2$ and $Y r 6$ react recessively in some cases (Macer, 1972; Labrum, 1980). The genes of the Yr 3 and Yr 4 loci seem more complex than the others. Lupton and Macer (1962) pointed out that Cappelle-Desprez ( $Y r$ $3 a$ ) may have an additional recessive gene ( $Y r 4 a)$ and Hybrid $46(Y r 4 b)$ an additional dominant gene ( $Y r 3 b)$. Each of the 4 remaining resistance factors is named after the reference variety in which it was found (Stubbs, 1985), ie, Strubes Dickkopf (SD), Suwon 92 Omar (Su), Carstens V (CV), and Spaldings Prolific (Spa). No race virulent for the $Y r 5$ gene has been isolated in surveys conducted in Europe. This gene, derived from Triticum spelta album, is not used in the current official differential variety set, which therefore includes 13 identified resistance genes.

The second type of specific resistance to yellow rust is apparent only during the adult plant stage, and its genetic control is currently less well understood. Genes of this type are designated Yr11 to $\operatorname{Yr} 14$ and $\operatorname{Yr} 16$ (Mclntosh, 1986). This paper describes studies on resistance at the seedling stage, which is a prerequisite for studies of adult plant resistance. The objective was to analyze: 1) specific resistance factors at the seedling stage in several of the most widely cultivated French varieties, and 2) the overall virulences of natural populations of yellow rust.

\section{MATERIALS AND METHODS}

\section{Choice of varieties}

Fifteen varieties of winter wheat from among those most widely cultivated in France in 1986 were tested: Festival, Fidel, Camp Rémy, Arminda, Talent, Beauchamp, Hardi, Gala, Corin, Scipion, Castan, Caton, Tango, Garant, Darius, and Top (anonymous, 1986). Darius and Gala are more typical of varieties grown in the South of France. Prinqual, a spring wheat on which yellow rust was found in 1986, was also used as were 3 older varieties (Champlein, Capitole, and Cappelle-Desprez) that are genealogically related to the first set. Four varieties that were infected in the epidemics of 1987 and 1988 (Thésée, Soissons, Récital, and Austerlitz) were also tested.

\section{Pathogenicity tests}

The seedlings were inoculated at the 2-leaf stage with a suspension of fresh uredospores in mineral oil (Soltrol 170, Philips, France) using a Burgerjon tower (1956). After $24 \mathrm{~h}$ of incubation at $8^{\circ} \mathrm{C}$ in the dark and at $100 \%$ humidity, the seedlings were placed in a climatic room maintained at $14^{\circ} \mathrm{C}$ during an 8-h dark period and at $17^{\circ} \mathrm{C}$ during a 16-h light period with a

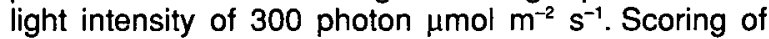
disease intensity 15 and 17 days after inoculation was carried out using 10 infection types (table I) defined by the presence of necroses and chloroses and the intensity of sporulation (McNeal et al, 1971). The tests carried out at Cambridge were scored using a 00-IV scale (Gassner and Straib, 1932). Approximate equivalence of the 2 scales is given in table 1. Each test was repeated $2-6$ times using $8-10$ seedlings per test.

\section{Choice of races for analyzing resistance genes}

To avoid the risk of introducing new yellow rust races into France, we worked mainly with isolates collected in France. The exception was race OEO, which does not possess virulence for any of the differential varieties and which was used to look for the presence of at least one resistance factor in the varieties tested. This race, which was provided by Dr Stubbs (IPO, Wageningen, The Netherlands), came from Bolivia and was multiplied on the variety Michigan Amber. Each of the 10 races used in the French tests was cloned from a single uredospore and multiplied using a specific variety in order to avoid accidental contamination. The virulence spectra of the races on the standard differential host set (Johnson et al, 1972) and their nomenclature are shown in table II. Although no formal genetic analysis of Vilmorin 23 and Nord Desprez 
Table I. 0-9 scale (McNeal et al, 1971) and 00-IV scale (Gassner and Straib, 1932) of yellow rust infection types on wheat seedlings.

$0-9 \begin{array}{lll}\text { Infection type } & \text { Description of symptoms } & \text { Classification of varieties }\end{array}$

No symptom

Necrotic or chlorotic flecks

No sporulation

Necrotic and/or chlorotic blotches (or stripes) No sporulation

Very to moderately resistant

Necrotic and/or chlorotic blotches (or stripes)

Trace sporulation

$\mathrm{I}^{+}-\mathrm{II}$

Necrotic and/or chlorotic blotches (or stripes)

Light sporulation

$\|-\left.1\right|^{+}$

Necrotic and/or chlorotic blotches (or stripes)

Intermediate sporulation

$6 \quad$ III-III

Necrotic and/or chlorotic blotches (or stripes)

Moderate sporulation

$7 \quad 11+$

Necrotic and/or chlorotic blotches (or stripes)

Abundant sporulation

Reduced chlorosis

Abundant sporulation

Moderately to very susceptible

No chlorosis

Abundant sporulation
Intermediately resistant

Table II. Reaction of the 14 tested races of Puccinia striformis on the official differential variety set and nomenclature of the races using a binary notation. Races are designated by a world number followed by a European (E) number, values of the varieties $\left(2^{*}\right)$ on which the race is virulent are summed (Johnson et al, 1972). $+=$ compatibility; $-=$ incompatibility; ${ }^{*}$ : the variety possesses at least one additional resistance factor (Stubbs, 1985); ${ }^{*}$ : very sensitive to light (Stubbs, 1967).

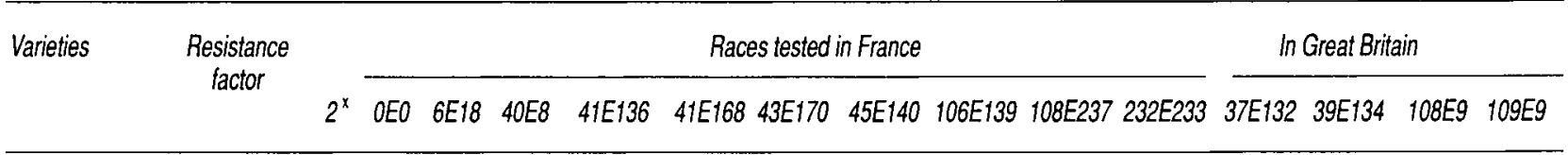

Official Differential Variety Set at the Seedling Stage

World Variety Set

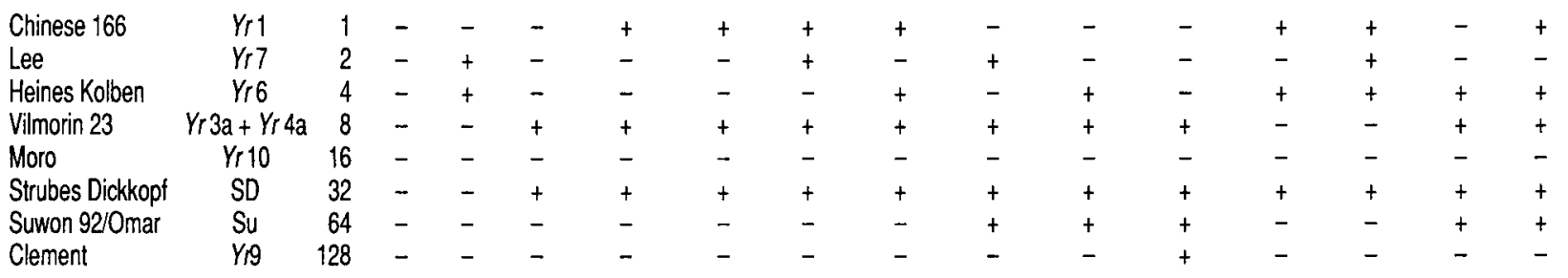

\section{European Variety Set}

\begin{tabular}{|c|c|c|c|c|c|c|c|c|c|c|c|c|c|c|c|c|}
\hline Hybrid 46 & $\gamma_{r} 3 b+\gamma_{r} 4 b$ & 1 & - & - & - & - & - & - & - & + & + & + & - & - & + & + \\
\hline Reichersberg 42 & $Y_{r} 7^{*}$ & 2 & - & + & - & - & - & + & - & + & - & - & - & + & - & - \\
\hline Heines Peko & $Y_{r} 6+Y_{r} 2$ & 4 & - & - & - & - & - & - & + & - & + & - & + & + & - & - \\
\hline Nord Desprez & $Y r 3 a+Y r 4 a$ & 8 & - & - & + & + & + & + & + & + & + & + & - & - & + & + \\
\hline Compair & Yr8 & 16 & - & + & - & - & - & - & - & - & - & - & - & - & - & - \\
\hline Carstens V** & CV & 32 & - & - & - & - & + & + & - & - & + & + & - & - & - & - \\
\hline Spaldings Prodific & Spa & 64 & - & - & - & - & - & - & - & - & + & + & - & - & - & - \\
\hline Heines VII & $Y_{r 2}$ & 128 & - & - & - & + & + & $t$ & + & + & + & + & + & + & - & - \\
\hline
\end{tabular}


studies has been presented, Zadoks (1961) showed that the reactions of these varieties were parallelled to those of Cappelle-Desprez and they are therefore listed as possessing $\mathrm{Yr} 3 a+Y r 4 a$ in table II. In order to test virulence combinations that are not known in France, 10 varieties were analyzed at the Plant Breeding Institute in Cambridge using 11 British races (37E132, 39E134, 108E9, 109E9, 104E137, 108E141, 109E141, 169E136, 171E138, and 232E137). Race $41 \mathrm{E} 136$ (the eleventh race) was tested both in France and in Great Britain.

\section{Survey of yellow rust races}

Sampling was conducted in collaboration with the Institut Technique des Céréales et des Fourrages (ITCF), the Service de la Protection des Végétaux (SPV), and breeders. The sample size was increased by inoculating a susceptible cultivar, Michigan Amber, with spores from the collected sporulating leaves. The samples were then analyzed using the European and world sets of 15 differential hosts (Johnson et al, 1972) and Clement $(\operatorname{Yr} 9)$, which was added to the world set after 1972 (Stubbs, 1985). Spores from each sample were stored in liquid nitrogen after a partial desiccation for 4 days at $5^{\circ} \mathrm{C}$ in a desiccator filled with glycerol.

\section{RESULTS}

Because of the extensive nature of the data only those races contributing to the discrimination of different resistance genes are presented, comprising 9 French and 4 British races (table III).

Table III. Infection types and postulated genes for seedling resistance to yellow rust carried by 21 wheat varieties presently grown in France and 3 earlier varieties used for pedigree analysis $\left(^{*}\right)$. For the races tested in France, infection type is indicated by a notation from 0 to 9 according to the McNeal et al' scale (1971). [R=resistance, infection types 0 6 ; $S=$ susceptibility, infection types $7-9$; I=intermediate reactions].

For the races tested in Great Britain, infection type is indicated by a notation from 00 to IV according to the Gassner and Straib' scale (1932). [R=resistance, infection types 00-II; S=susceptibility, infections type II--IV; I=intermediate reactions]. $x, y$ indicates segregation between plants for infection type with the commonest infection type first; $x-y$ indicates a range of infection types on different plants without clear segregation into discrete classes; $x / y$ indicates different infection types on the first and second leaves; - no data; + in the last column indicates that there is at least another unidentified postulated gene.

\begin{tabular}{|c|c|c|c|c|c|c|c|c|c|c|c|}
\hline \multirow[t]{2}{*}{ Varieties } & \multirow[b]{2}{*}{$6 E 18$} & \multirow[b]{2}{*}{$40 E 8$} & \multirow[b]{2}{*}{$\begin{array}{l}41 E 136 \\
41 E 168\end{array}$} & \multicolumn{4}{|c|}{ Races tested France } & \multicolumn{3}{|c|}{ In Great Britain } & \multirow{2}{*}{$\begin{array}{l}\text { Postulated } \\
\text { resistance } \\
\text { genes }\end{array}$} \\
\hline & & & & $43 E 170$ & $45 E 140$ & $106 E 139$ & $108 E 237$ & 232E233 & $\begin{array}{l}37 E 132 \\
39 E 134\end{array}$ & $\begin{array}{l}108 E 9 \\
109 E 9\end{array}$ & \\
\hline Cappelle* & $\mathrm{R}(2)$ & $S(6-7)$ & $S(8)$ & $S(7)$ & $S(7)$ & $\mathrm{S}(7)$ & $S(7)$ & $S(7)$ & $\mathrm{R}(00)$ & $\mathrm{S}\left(\mathrm{IV}^{-}\right)$ & $\operatorname{Yr} 3 \mathrm{a}$ \\
\hline Champlein ${ }^{*}$ & $R(2)$ & $S(6-7)$ & $S(8)$ & $S(7)$ & $S(7)$ & $s(7)$ & $S(7)$ & $S(7)$ & $R(00)$ & S(IV-II|') & Yr3a \\
\hline Capitole* & $R(3)$ & $s(6-7)$ & $S(8)$ & $S(7)$ & $S(7)$ & $s(7)$ & $S(7)$ & $s(7)$ & $I(0-\||| / V) ; I\left(I^{+}\right)$ & $1(11) ; 1\left(0,1+1 V^{-}-0\right)$ & \\
\hline Top & $\mathrm{R}(2)$ & $S(7)$ & $S(8)$ & $S(7)$ & $S(7)$ & $S(7)$ & $s(7)$ & $S(7)$ & $\mathrm{R}(00)$ & $S\left(\mathrm{IV}^{-}\right)$ & Yr 3a \\
\hline Darius & $R(3-4)$ & $S(6-7)$ & $S(7)$ & $S(7)$ & $S(7)$ & $S(7)$ & $S(7)$ & $S(7)$ & $\mathrm{S}\left(\mathrm{IV}^{-}, \mathrm{II}^{+}\right)$ & $R(00)$ & Yr2 \\
\hline Festival & $R(5)$ & $S(6-7)$ & $S(7)$ & $S(8)$ & $S(7)$ & $s(7)$ & $S(7)$ & $s(7)$ & $S(I V, I I I)$ & $S\left(I^{-}, I I I\right)$ & (SD) \\
\hline Fidel & $R(2)$ & $1(5-6)$ & $\mathrm{s}(7)$ & $S(7)$ & $S(7)$ & $s(7)$ & $s(7)$ & $s(7)$ & S(IV) & $S\left(I V^{-}, I I^{+}\right)$ & (SD) \\
\hline Gala & $R(2)$ & $S(6-7)$ & $s(7)$ & s(7) & $s(7)$ & $s(7)$ & $s(7)$ & $s(7)$ & $S(I I I)$ & S(III) & (SD) \\
\hline Castan & $\mathrm{R}(2)$ & $S(6-7)$ & $s(7)$ & $s(7)$ & $S(7)$ & $s(7)$ & $s(7)$ & $s(7)$ & $\mathrm{S}\left(\mathrm{III}^{+}\right)$ & S(IV) & (SD) \\
\hline Caton & $R(2-3)$ & $1(5-6)$ & $S(7)$ & $1(5-6)$ & $\mathrm{I}(5-6)$ & $S(6-7)$ & $S(7)$ & $S(7)$ & $\mathrm{R}(\mathbf{I N})$ & $\mathrm{I}(\mathrm{II}, 0)$ & \\
\hline Corin & $R(1)$ & $\mathrm{R}(1)$ & $\mathrm{S}(7)$ & $\mathrm{S}(7)$ & $S(7)$ & $R(1)$ & $R(1)$ & $R(1)$ & - & - & $Y_{r} 1+$ \\
\hline Beauchamp & $\mathrm{R}(3)$ & $R(3-4)$ & $S(7)$ & $S(6-7)$ & $S(7)$ & $S(7)$ & $S(7)$ & $S(6-7)$ & - & - & $Y r 2+$ \\
\hline Prinqual & $S(7)$ & $R(3)$ & $R(4)$ & $S(7)$ & $\mathrm{R}(3)$ & $S(6-7)$ & $R(3-4)$ & $R(4)$ & - & - & Yr7 \\
\hline Talent & $S(7)$ & $R(3)$ & $R(3)$ & $S(7)$ & $\mathrm{R}(3)$ & $S(7)$ & $R(3-4)$ & $R(4)$ & - & - & Yr7 \\
\hline Tango & $S(7)$ & $\mathrm{R}(3)$ & $R(3-4)$ & $S(7)$ & $\mathrm{R}(3)$ & $S(7)$ & $\mathrm{R}(3)$ & $R(4-5)$ & - & - & Yr7 \\
\hline Garant & $\mathrm{R}(2)$ & $\mathrm{R}(3)$ & $R(4)$ & $S(7)$ & $\mathrm{R}(2)$ & $S(7)$ & $\mathrm{R}(3)$ & $R(4-5)$ & - & - & $Y_{r} 7+$ \\
\hline Hardi & $R(4)$ & $R(3)$ & $R(3)$ & $S(7)$ & $R(2-3)$ & $S(6-7)$ & $R(3)$ & $R(3)$ & - & - & $Y r 7+$ \\
\hline Arminda & $\mathrm{R}(3)$ & $R(2)$ & $R(3)$ & $R(4)$ & $R(2-3)$ & $\mathrm{R}(5)$ & $\mathrm{R}(3-4)$ & $R(3)$ & - & - & \\
\hline Camp Rémy & $\mathrm{R}(3)$ & $R(2)$ & $R(3)$ & $\mathrm{R}(4)$ & $\mathrm{R}(2)$ & $R(5)$ & $R(3)$ & $R(3)$ & - & - & \\
\hline Scipion & $R(4)$ & $S(6-7)$ & $S(7)$ & $S(7)$ & $S(7)$ & $S(7)$ & - & $S(7)$ & - & - & Yr3a \\
\hline Soissons & $R(2)$ & $S(8)$ & $S(7)$ & $S(7)$ & $S(7)$ & $S(7)$ & - & $S(7)$ & - & - & $\operatorname{rr} 3 a$ \\
\hline Thésée & $R(3)$ & $R(2)$ & $S(7)$ & $S(7)$ & $S(7)$ & $S(7)$ & - & $S(7)$ & - & - & $\operatorname{Yr} 2+$ \\
\hline Austerlitz & $\mathrm{R}(2)$ & $R(2)$ & $R(1)$ & $R(1-2)$ & $S(7)$ & $\mathrm{R}(2)$ & - & $R(1-2)$ & - & - & $\operatorname{Vr} 6+$ \\
\hline Récital & $S(6-7)$ & $R(2)$ & $R(3,1)$ & $R(2-3)$ & $S(7)$ & $R(2)$ & - & $R(2 / 6)$ & - & - & $\operatorname{Vr} 6$ \\
\hline
\end{tabular}




\section{Expression of specific resistance}

It is important to note that the 10 infection types shown in table I are needed to describe the different levels of resistance observed. According to this scale, some varieties react to a given race hypersensitively, developing small necrotic points (infection type 1) and are easily classified as resistant. This occurs in the case of Corin infected with races 6E18, 40E8, 106E139, 108E237, and 232E233. Other varieties have sporulation accompanied by large chloroses (infection types 4-5). These infection types represent moderate disease intensity corresponding to an intermediate type of resistance that is sometimes difficult to evaluate, especially because it seems particularly dependent on environmental conditions. This is the case, for example, for Garant and Tango infected with race 232E233.

Races 6 E18 and 40 E8 were slower to show symptoms than other races and often produced intermediate type reactions. Higher infection types were obtained by increasing the temperature maintained during infection development $\left(16^{\circ} \mathrm{C}\right.$ at night $/ 19^{\circ} \mathrm{C}$ during the day). The results given in table III include this temperature increase for these 2 races.

\section{Methods for determining resistance factors}

The postulation of specific resistance factors was made by application of the gene-for-gene hypothesis developed by Flor (1956), ie, for every resistance gene of the host there is a corresponding avirulence gene of the parasite. No sexual stage has been found in $P$ striiformis, and the hypothesis therefore cannot be tested by a genetic study of this organism. However, the pattern of race-variety interactions is consistent with the operation of a gene-for-gene system, which is therefore applied in the interpretation of the results. The methodology chosen for ascertaining specific resistance factors in the varieties is the successive inoculation of these varieties by races previously identified using the set of 16 differential hosts. Incompatible reactions are epistatic over compatible (susceptible) reactions. Thus a high infection type signifies that the variety does not possess any of the genes for which the race is known to be avirulent. It could, however, possess genes corresponding to those for which the race carries virulence. Therefore, compatible reactions obtained as a result of infection of a variety by a simple race, ie, a race with a low number of virulences, were used to indicate the absence of any resistance genes for which the race lacks virulence. Then the examination of incompatible reactions permitted elimination of some hypotheses concerning the possible combinations of resistance factors. For example, the susceptibility of the variety Prinqual to the race 6E18 indicated that, of the 13 resistance factors tested, only $\operatorname{Yr} 6, \operatorname{Yr} 7$, and $\operatorname{Yr} 8$ could be concerned. However, Prinqual's susceptibility to 43E170 showed that $\operatorname{Yr} 7$ was the only useful hypothesis because this race lacks virulence for Yr6 and $\operatorname{Yr} 8$.

\section{Hypotheses concerning the resistance factors carried by the varieties tested}

None of the varieties tested was susceptible to the race $0 \mathrm{E} 0$, indicating that they all possess at least one resistance factor. Among the 24 varieties studied, 14 were susceptible to the majority of the races tested, in particular to $41 \mathrm{E} 136$ and 232E233. The 3 resistance factors that could be present in these varieties are therefore SD, Yr2, and $\left(Y_{r} 3 a+Y r 4 a\right)$. The only race available in France for improving upon this hypothesis was 40E8, avirulent for $Y_{r} 2$ and virulent for $S D$ and $(Y r 3 a+Y r 4 a)$. This race is weakly aggressive under the usual testing conditions of $P$ striiformis $\left(14^{\circ} / 17^{\circ} \mathrm{C}\right)$, where it often causes intermediate infection types. Higher infection types were obtained by increasing the temperature by 2 degrees. In this way, 12 of the 14 varieties tested (the exceptions being Beauchamp and Thésée) developed infection types ranging from $6-7$. This suggests that $S D$ and/or $(Y r 3 a+Y r 4 a)$ satisfy the conditions of the hypothesis for the 12 varieties and $Y r_{2}$ and possibly SD and/or (Yr3a + Yr 4a) for Beauchamp and Thésée.

Because of the difficulties encountered in tests with race $40 \mathrm{E} 8$ and also the inability of this race to discriminate between $S D$ and $(Y r 3 a+Y r 4 a)$, the resulting hypotheses remained unsubstantiated. Additional tests were therefore conducted in Great Britain on the first 10 varieties shown in table III. One race, 41E136, used in both countries, and 2 closely related races, 232E137 in Great Britain and 232E233 in France, were found to be virulent for 8 of the 10 varieties, confirming that the possible resistance genes are $\mathrm{SD}, \quad Y_{r} 2$, and $\left(Y_{r} 3 a+Y_{r} 4 a\right)$. The remaining varieties, Capitole and Caton, showed intermediate reactions with one of the 2 isolates of $41 \mathrm{E} 136$ tested. Table III shows only the 4 British races that added further to the hypotheses. These races, which permitted separation of SD, $Y r 2$, and $(Y r 3 a+Y r 4 a)$, were $37 \mathrm{E} 132$ and $39 \mathrm{E} 134$, virulent for $\mathrm{SD}$ and $Y r 2$ and avirulent for $(\operatorname{Yr} 3 \mathrm{a}+\mathrm{Yr} 4 \mathrm{a})$, and $108 \mathrm{E} 9$ and 
109E9, virulent for SD and $(Y r 3 a+Y r 4 a)$ and avirulent for $Y r 2$. In addition, the 5 other British races (104E137, 108E141, 109E141, 169E136, and $171 \mathrm{E} 138$ ), which were virulent for those 8 varieties, supported the preceding hypotheses. If any of these latter races had been found to be avirulent, it could have indicated that the tested varieties had other genes, as suggested below for different reactions of Capitole and Caton to the 2 isolates of race $41 \mathrm{E} 136$ used in the tests.

The susceptibility of Cappelle-Desprez, Champlein, and Top to 108E9 and 109E9 indicated that these varieties do not carry Yr 2. Their resistance to $37 \mathrm{E} 132$ and $39 \mathrm{E} 134$ is consistent with the presence of $(\operatorname{Yr} 3 a+Y r 4 a)$ as is their susceptibility to race 40E8. For simplification, $Y_{r} 3 a$ instead of $(Y r 3 a+Y r 4 a)$ is reported in table III.

The opposite reactions were obtained with these 2 sets of British races for the variety Darius, which was fully susceptible to $37 \mathrm{E} 132$ and 39E134 and developed low infection types with 109E9 and 108E9. In this case, Yr2 satisfied the hypothesis. However, the susceptible reaction of Darius to race 40E8, which is thought to lack virulence for $Y_{r} 2$, requires further investigation.

The susceptibility of Castan, Festival, and Gala to $40 \mathrm{E} 8$ and to the 4 British races presented in table III suggested that, of the 3 possibilities, $i e, \mathrm{SD}, \operatorname{Yr} 2$, and $(Y r 3 a+Y r 4 a)$, only SD was consistent with the data. Fidel, which had intermediate infection type (5-6) with 40E8 and was fully susceptible to the same 4 British races, could also have SD.

In the tests conducted in Great Britain with Capitole, the races lacking virulences for $Y_{r 2}$ and $(Y r 3 a+Y r 4 a)$ gave intermediate reactions: infection type $1 I^{+} \mathrm{N}$ with $39 \mathrm{E} 134$, infection types $I^{-} \mathrm{N}-\mathrm{I}^{+} \mathrm{N}$ with $108 \mathrm{E} 9$, and low infection types on the first leaf and sometimes complete susceptibility on the second leaf with $37 \mathrm{E} 132$ and 109E9. Capitole was fully susceptible to most of the races having virulences for $Y{ }_{2}$ and $(Y r 3 a+\operatorname{Yr} 4 a)$ [41E136 (isolate WYR 72/40), 169E136, 171E138, and 232E137]. The exceptions were 108E141 and 104E137, whose reactions ranged from resistant to intermediate; 109E141, whose reactions ranged from highly susceptible to resistant; and the second isolate of 41E136 (WYR68/1), which induced resistance on the first leaf and varied from intermediate to resistant reactions on the second. Parallel reactions of Caton to the 2 isolates of $41 E 136$ were observed (susceptibility to WYR 72/40 and resistance to WYR 68/1). The presence of a range of reactions could be generally explained by the influence of different environmental conditions and, in the case of the 2 isolates of $41 \mathrm{E} 136$ on Capitole and Caton, by differences in the virulence spectra that were not detected with the differentials. The available data, which could be supplemented through additional testing, cannot be explained solely by known resistance genes. Given their similar reactions, it is worth noting that Capitole is a parent of Caton.

Corin had at least $\operatorname{Yr} 1$. Because of the associations of virulences in the races used, it was not possible to prove that $\mathrm{Yr} 2$ and/or $($ Yr3a + Yr 4a) were also present. Prinqual, Talent, and Tango, which were susceptible to $6 \mathrm{E} 18$ and $43 \mathrm{E} 170$, appeared to possess $\mathrm{Yr} 7$. Garant and Hardi seemed to have 2 resistance factors, one being $Y r 7$ and the other $Y / 2$ or $\left(Y_{r} 3 a+Y r 4 a\right)$. Camp Rémy and Arminda, which were resistant to all races tested, could have a combination of 2 or 3 of the named genes or other unknown genes that could not be overcome by the available races.

Because Austerlitz was susceptible to $45 \mathrm{E} 140$ and resistant to both $41 \mathrm{E} 136$ and $6 \mathrm{E} 18$, it may have $Y r 6$ and, in addition, $Y r 2$ and/or $\left(Y_{r} 3 a+Y_{r} 4 a\right)$. Récital, differing from Austerlitz through its susceptibility to $6 \mathrm{E} 18$, may have only Yr6. Also unlike Austerlitz, the reaction of Récital was strongly dependent on light intensity, higher infection types occurring under the same conditions in which Carstens $V$ gave higher infection types. Finally, Récital differed from Austerlitz by sometimes having dissimilar infection types on its first and second leaves.

Reference to varietal pedigrees can help to explain the limited number of genes involved and to revise hypotheses concerning the genetic make-up of varieties. The relation of tested varieties to resistance sources is shown in figure 1 . The majority of the varieties have Cappelle-Desprez in their pedigrees and could therefore have inherited the resistance genes $\mathrm{Yr}$ 3a and $\mathrm{Yr}$ 4a reported in this variety by Lupton and Macer (1962). Several varieties including Talent, Hardi, and Garant appear to possess $Y r 7$ derived from Thatcher (McIntosh, 1983). Hardi also descends from Cappelle-Desprez $(\operatorname{Yr} 3 a+\operatorname{Yr} 4 a)$ and Garant from Maris Widgeon (Yr3a + Yr 4a) according to Taylor et al (1981) and therefore probably have $(Y r 3 a+Y r 4 a)$ rather than $\mathrm{Yr} 2$.

Top, one of whose parents is CappelleDesprez, and Castan, Caton, Soissons, and Scipion, one of whose parents is Champlein $(Y r 3 a+Y r 4 a)$, can also be expected to carry this gene pair.

Similarly, Thésée could possess $Y r 2$ derived from Maris Huntsman ( $Y r 2+Y r 3 c)$ (McIntosh, 1983), and Corin can be expected to have $Y r 1$ 


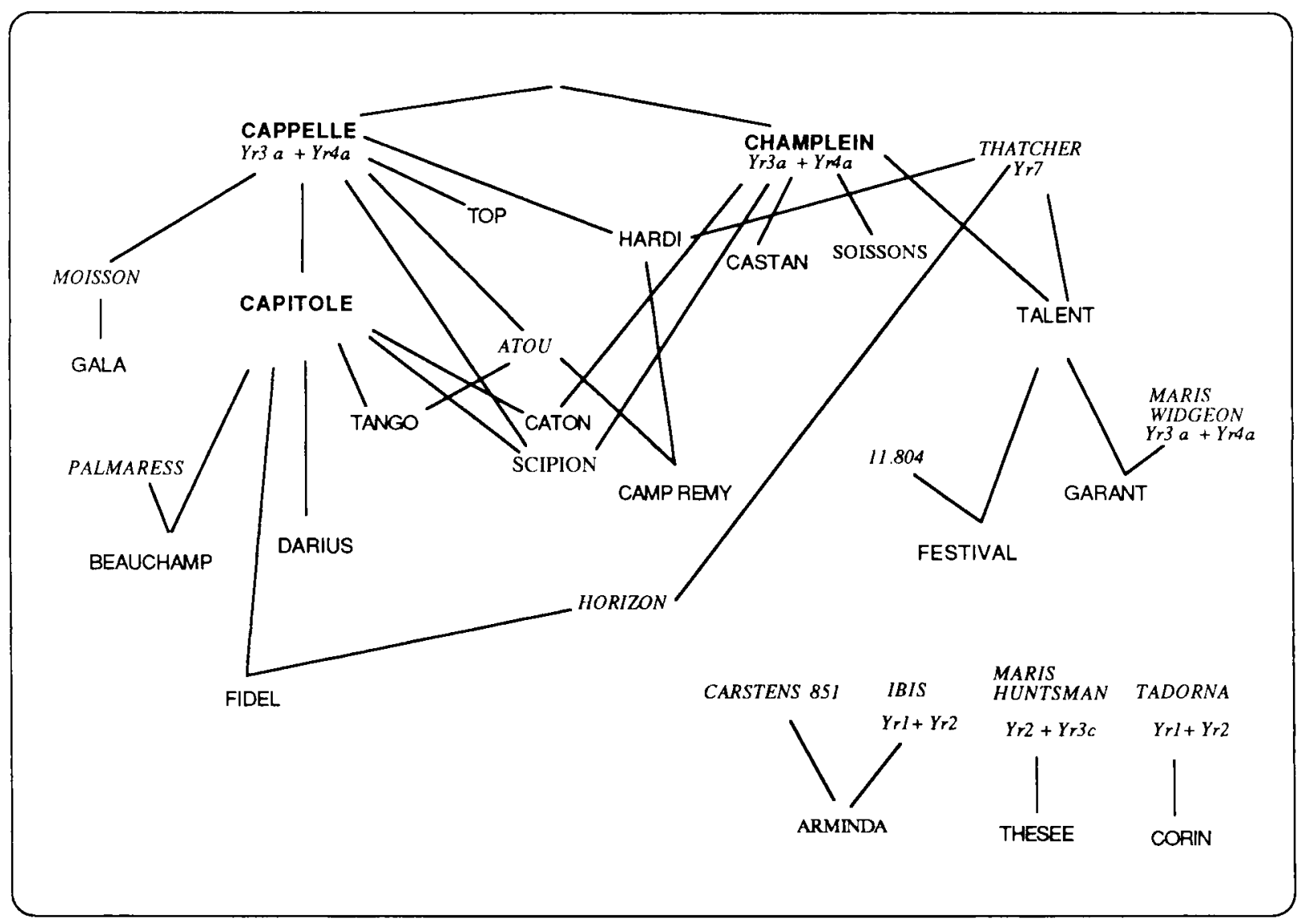

Fig 1. Relations of varieties grown in France to sources of resistance to yellow rust (Joudrier, 1974). A line between 2 varieties indicates that the pedigree of the lower one contains the higher variety. Varieties in italics were not included in the study.

and, should there be a second gene, Yr2, derived from Tadorna $(Y r 1+$ Yr2).

Camp Rémy, which is derived from Hardi and, indirectly, Cappelle-Desprez, could carry ( $Y r 3 a+$ Yr 4a) and $\operatorname{Yr} 7$. Because it is resistant to the races $43 \mathrm{E} 170$ and 106E139, it must have at least one more resistance factor, which could be $\operatorname{Yr} 6$, $\mathrm{Yr} 8$, or $\mathrm{Yr} 9$ from the presented data.

\section{Surveys of $\mathrm{P}$ striiformis races}

A survey of yellow rust races was carried out beginning in 1984. The results obtained from that date through 1988 are recorded in table IV. In 1984 and 1985 no significant epidemic occurred. In consequence, the isolates analyzed in those 2 years came essentially from populations maintained by breeders in their nurseries for screening, the lines being selected through the mixture of spores collected the previous year. Analysis of 23 isolates from 3 areas showed that the inoculum was made up mainly of the races $43 E 138$ and $43 E 170$.

In 1986, a natural epidemic in the spring wheat Prinqual in the Rhône-Alpes area was caused by the race $6 \mathrm{E} 18$, whose virulence spectrum is unlike that of the majority of races because of its avirulence on SD and virulence on $Y_{r} 8$ and $\operatorname{Yr} 7$, and was able to overcome the resistance $\operatorname{Yr} 7$ carried by Prinqual. This race was also found in a sample from the hard wheat Regal.

The 1987 natural epidemic was moderate. Samples from 3 regions (Normandie, lle de France, and Rhône-Alpes) indicated that the epidemic was initiated principally by 45E140, $41 \mathrm{E} 136$, and $45 \mathrm{E} 172$, the first 2 races having virulence formulae that differ only with regard to Yr6 and the third possessing the same virulence factors as $45 \mathrm{E} 140$ with additional virulence for Carstens V.

The 1988 natural epidemic was more severe. Using Zadoks's model (1971) revised by Rapilly (1976), the number of potential cycles was calculated. There were 12 infection cycles between November 1987 and March 1988, significantly greater than the number occurring during the 2 previous epidemics ( 7 for 1986 and 3 for 1987). Samples from 7 regions (Nord, Picardie, Pays de la Loire, lle de France, Bourgogne, Rhône-Alpes, and Bretagne) 
Table IV. The number of isolates of $P$ strifformis races observed over the 5-year period 1984-1988 and the virulence factors for these same races.

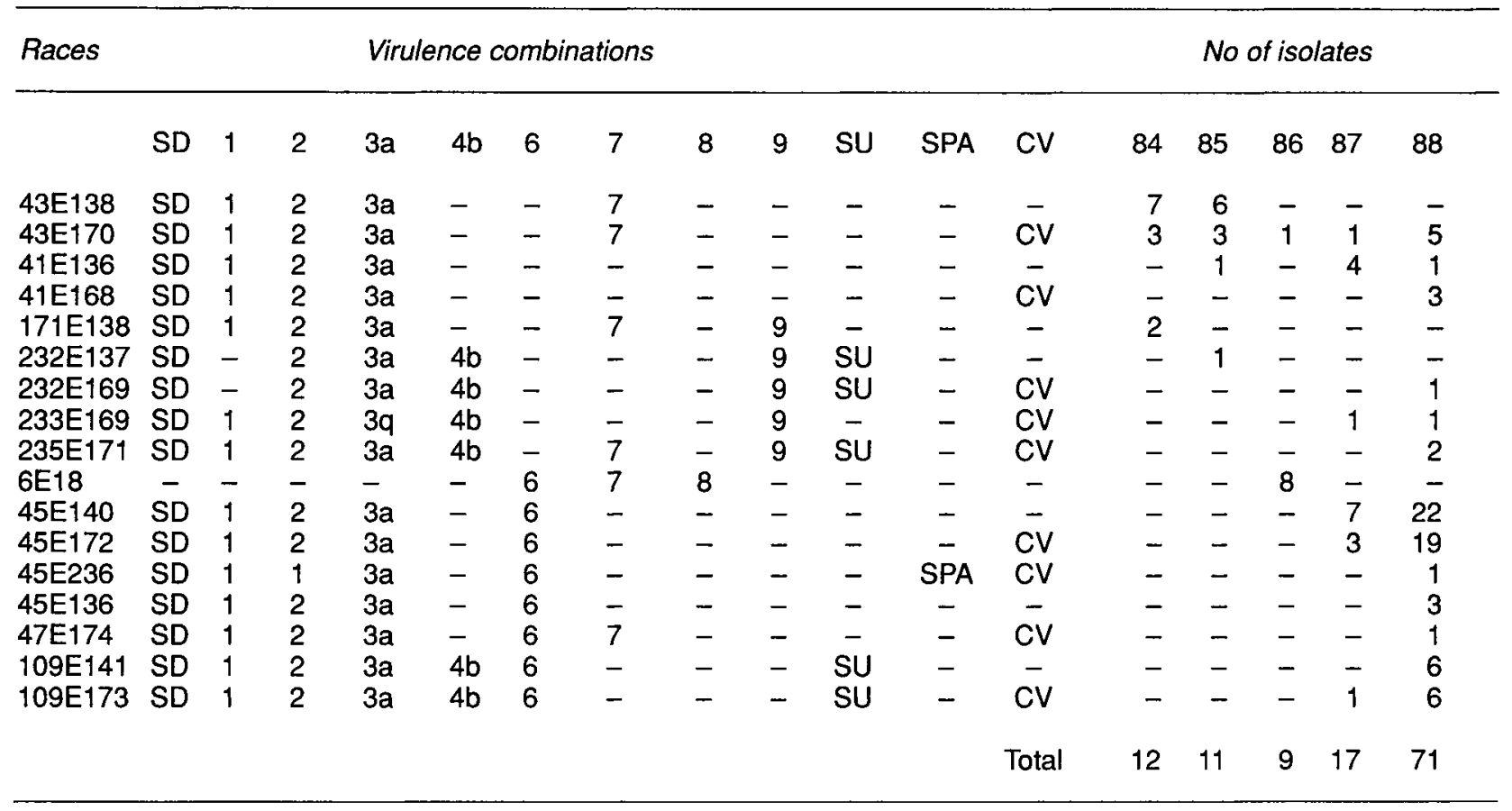

Table V. The number of isolates of $P$ striiformis races collected from varieties cultivated in France from 1984-1988.

\begin{tabular}{|c|c|c|c|c|c|c|c|c|}
\hline \multirow[t]{2}{*}{ Varieties } & \multicolumn{8}{|c|}{ P striiformis races } \\
\hline & $\begin{array}{l}43 E 138 \\
43 E 170\end{array}$ & $171 E 138$ & $6 E 18$ & $\begin{array}{l}41 E 136 \\
41 E 168\end{array}$ & $\begin{array}{l}232 E 137 \\
232 E 169 \\
233 E 169 \\
233 E 171\end{array}$ & $\begin{array}{l}45 E 140 \\
45 E 172 \\
45 E 236 \\
45 E 136\end{array}$ & 47E174 & $\begin{array}{l}\text { 109E141 } \\
109 E 173\end{array}$ \\
\hline Prinqual & - & - & 7 & - & - & - & - & - \\
\hline Thésée & 1 & - & - & 5 & 2 & 23 & - & 3 \\
\hline Récital & - & _- & - & - & 1 & 10 & - & 6 \\
\hline Austerlitz & - & - & - & - & 1 & 5 & - & 1 \\
\hline Fidel & 1 & - & - & - & - & 2 & - & - \\
\hline Viking & - & - & - & - & - & 2 & - & - \\
\hline Duck & - & - & - & - & - & 2 & - & - \\
\hline Others & 23 & 2 & 1 & 4 & 2 & 11 & 1 & 4 \\
\hline
\end{tabular}

suggested that the epidemic was caused principally by $45 \mathrm{E} 140$ and $45 \mathrm{E} 172,2$ of the races already detected the previous year. The races 109E141 and 109E173, which differed from the former by having 2 additional virulences, those matching Su and $(Y r 3 b+Y r 4 b)$, were also common. It should be noted that a single instance of $109 \mathrm{E} 173$ was recorded in the much smaller sample made in 1987.

Table $V$ lists the varieties on which at least 2 isolates were identified over the 5-year period studied and indicates for each variety the number of isolates per race. The table shows that, of these varieties, Thésée and Récital were the most affected, this occurring during the epidemics of 1987 and 1988. The remaining varieties, with the exception of Prinqual, ie, Austerlitz, Fidel, Viking, and Duck, were primarily affected by $45 \mathrm{E} 140$ and $45 \mathrm{E} 172$.

\section{DISCUSSION}

The present study on specific resistance factors demonstrates the importance of considering the results of each race-variety pair. Successive elimination of genes that cannot be present because of the susceptible reactions observed 
with races carrying the lowest number of virulences can provide a tentative identification of one or more postulated genes. The advantage of having a large set, and consequently a more random sample, of virulence combinations became apparent, in particular for deciding between SD, $(Y r 3 a+Y r 4 a)$, and $Y r 2$ for which there was insufficient variation between the French races alone, but which was possible with the addition of some British races. However, some of the findings were inconsistent with interpretations based on known resistance genes, such as with Darius, indicating the limits of such tests for determining the resistance genes in varieties. Such inconsistencies may be due to unrecognized virulence in the races used. Nevertheless, the data can assist in the selection of varieties that could be crossed for detailed genetic analyses. Furthermore, the use of a large set of races (9 French and 11 British) helped in postulating resistance genes, because corresponding data from many different races support a given hypothesis, and variable data may also provide the opportunity to discover variation between races that is not revealed by the differential set. Such a discovery could permit identification of previously unknown genes.

The method of successive elimination showed that, for the races currently present in France, the French varieties under cultivation possess, on average, only 1-3 known resistance factors simultaneously and that only 6 resistance factors out of the 13 tested were present, ie, SD, Yr 1, Yr2, $(Y r 3 a+Y r 4 a), Y r 6$, and $Y r 7$. The data therefore indicate that a small number of the known race-specific resistance genes are widely distributed in important French wheat varieties. This situation can be explained by the mostly accidental nature of the introduction of specific resistance factors found in commercial varieties. For example, Cappelle-Desprez, often used as a parent because of its high yield, could transmit (Yr 3a + Yr 4a) to a proportion of its descendants randomly without conscious selection (Röbbelen and Sharp, 1978). In contrast, deliberate introduction of genes resistant to yellow rust has been practiced at the PBI in Great Britain over the last several years. For that reason, most British commercial varieties carry not only the genes ( $Y r 3 a+Y r 4 a)$ from Cappelle-Desprez but also $\operatorname{Yr} 1, \operatorname{Yr} 2, \operatorname{Yr} 6$, and $\operatorname{Yr} 9$ (Taylor et al, 1981). Bayles et al (1988) have noted the increased popularity in the early to mid 1980's of varieties with $Y_{r} 1, Y_{r} 2,\left(Y_{r} 3 a+Y r 4 a\right)$, and $Y_{r} 6$ or $Y_{r} 1$, $\operatorname{Yr} 2$, $(Y r 3 a+Y r 4 a)$, and $(Y r 3 b+Y r 4 b)$. More recently WYR 14, a specific resistance gene at the adult plant stage, has occurred frequently in these varieties.
Three varieties, Arminda, Camp Rémy, and Mission (Bayles and Herron, 1986), were resistant to all the races used and therefore their resistance genotype could not be determined. They may have unknown genes or combinations of the known race-specific genes that could not be matched by any of the races used. The widespread cultivation of Camp Rémy and Arminda for several years in France without the occurrence of yellow rust on them may suggest that they possess a genotype that provides durable resistance, but this could not be demonstrated with the present data. A genetic study in which Camp Rémy is crossed with a variety that does not have $(Y r 3 a+Y r 4 a), \operatorname{Yr} 7$, $\operatorname{Yr} 6, Y r 8$ and $Y r 9$, and in which the descendants are tested with races having virulence for $\operatorname{Yr} 6, \operatorname{Yr} 8$, or $\operatorname{Yr} 9$ would be an appropriate next step for determining Camp Rémy's genotype.

The virulences carried by the population of $P$ striiformis correspond to the specific resistance genes in cultivated varieties. The races surveyed in France in 1984 and 1985 possessed the virulence factors corresponding to the resistance genes $\operatorname{Yr} 1, \operatorname{Yr} 2,(Y r 3 a+Y r 4 a)$, and $Y r 7$, which were assumed to be present in the most widely cultivated varieties in 1986 . Since then, natural epidemics have been caused by races that differ from the previous ones by their virulence for $Y r 6$ and avirulence for $\operatorname{Yr} 7$. This situation can be explained by the decreasing cultivation of Talent $(\mathrm{Yr} T)$ and the increasing popularity of $\mathrm{Yr}$ carrying varieties like Austerlitz, Récital, and Moulin (Bayles and Thomas, 1984).

Comparison between the races found in the French survey and those reported in the UK Cereal Pathogen Virulence Survey is not straightforward, the latter being based on a differential set limited to those varieties possessing resistance factors $Y r 1$ through $Y r 10$ but not SD, Su, Spa, and CV. The dominant races are virulent for the gene sets $\operatorname{Yr} 1, \operatorname{Yr} 2$, $\left(Y_{r} 3 a+\operatorname{Yr} 4 a\right), \quad \operatorname{Yr} 6$ and $\operatorname{Yr} 1, \quad \operatorname{Yr} 2, \quad(Y r 3 a$ + Yr 4a), (Yr3b+Yr 4b), Yr6 (Bayles et al, 1988), which are found in France in the races $45 \mathrm{E} 140$ and 45E172 and in the races 109E141 and 109E173, respectively. In the same way, the dominant races in France were isolated in the Netherlands in 1988; 109E141 was found for the first time and 45E140 was identified after an absence of 10 years (Stubbs, personal communication).

The appearance in France of races like $109 E 173$ (virulent for $\operatorname{Yr} 1, \operatorname{Yr} 2, \operatorname{Yr} 3 a+\operatorname{Yr} 4 a$, $Y_{r} 3 b+Y_{r} 4 b, Y r 6, S u$, and CV) having complex virulence combinations parallels the situation found in Great Britain over a longer period. The 
simple combination of virulences for $Y r 1, Y r 2$, and $\mathrm{Yr} 3 \mathrm{a}+\mathrm{Yr} 4 \mathrm{a}$, which was the most common in Great Britain in the late 1970's and early 1980 's, has been replaced by more complex races such as those with virulence for the gene sets $Y_{r} 2,\left(Y_{r} 3 a+\operatorname{Yr} 4 a\right),(Y r 3 b+Y r 4 b), \operatorname{Yr} 6$ and $Y_{r} 1, Y_{r 2}\left(Y_{r} 3 a+Y_{r} 4 a\right),\left(Y_{r} 3 b+Y r 4 b\right)$, Yr6. This trend towards increasing complexity has consequences for strategies for using resistance genes. The introduction into commercial varieties of combinations of specific resistance genes corresponding to combinations of virulences that are not yet present in France, eg $(\operatorname{Yr} 6+\operatorname{Yr} 9)$, could offer a simple means of protecting varieties beginning at the seedling stage. Camp Rémy, which appears to be resistant to yellow rust from the seedling stage, may be an example of a variety into which a set of specific resistance genes was introduced. However, even if this resistance appeared to be satisfactory for Camp Rémy, the commonly shortterm nature of a strategy combining specific resistance genes makes it advisable to search for another kind of resistance.

Adult plant resistance can be assessed using virulent races at the seedling stage. This test is currently being carried out at GEVES (La Minière, France) before varieties are inscribed on the official list. Although adult plant resistance is often believed to be more durable, instances were found in which such resistance was highly race-specific and not durable (Zadoks, 1961; Johnson and Taylor, 1972; Johnson, 1978).

No test, whether comprising multiple locations or multiple races, is satisfactory for assessing the resistance durability of a variety during a breeding programme (Johnson, 1984). As a consequence, it is proposed that a diversification scheme be applied (intra- or inter-field) using commercial varieties having different resistance factors that are efficient towards a large part of the parasite population (Priestley and Bayles, 1980; Wolfe, 1985; de Vallavieille-Pope et al, 1988) in order to limit the exposure of each variety at risk to the severe test for durability, ie, large area, long period of time, and favourable environmental conditions for epidemics.

\section{ACKNOWLEDGMENT}

The authors are grateful to Dr Stubbs for his useful comments.

\section{REFERENCES}

Anonymous (1986) Ministère de l'Agriculture. Service Central des Enquêtes et Etudes Statistiques.
Situation Agricole en France. Note de Conjoncture Production Végétale, 52-60

Bayles RA, Thomas JE (1984) UK Cereal Pathogen Virulence Survey, 1987. Ann Rep UK Cereal Pathogen Virulence Survey Committee, Cambridge, 18-28

Bayles RA, Herron CM (1986) UK Cereal Pathogen Virulence Survey, 1987. Ann Rep UK Cereal Pathogen Virulence Survey Committee, Cambridge, 15-20

Bayles RA, Channel MH, Stigwood PL (1988) UK Cereal Pathogen Virulence Survey, 1987. Ann Rep UK Cereal Pathogen Virulence Survey Committee, Cambridge, 11-16

Bingham $J$ (1981) Breeding wheat for disease resistance. In: Strategies for the Control of Cereal Disease (JF Jenkyn, RT Plumb, eds) Blackweil Scientific Publications, 3-14

Burgerjon A (1956) Pulvérisation et poudrage au laboratoire par des préparations pathogènes insecticides. Ann Epiphyt Phytogenet 22, 675-684

Flor HH (1956) The complementary genic systems in flax and flax rust. Adv Genet 8, 29-54

Gassner G, Straib W (1932) Die Bestimmung der biologischen Rassen des Weizengelbrostes (Puccinia glumarum f sp tritici (Schmidt) Erikss and Henn). Arb Biol Abt (Anst-Reichsanst) Berl 20, 141163

Johnson R (1978) Practical breeding for durable resistance to rust diseases in self-pollinating cereals. Euphytica 27, 529-540

Johnson R (1984) A critical analysis of durable resistance. Ann Rev Phytophathol 22, 309-330

Johnson R, Taylor AJ (1972) Isolates of Puccinia striiformis collected in England from the wheat varieties Maris Beacon and Joss Cambier. Nature (Lond) 238, 105-106

Johnson R, Stubbs RW, Fuchs E, Chamberlain NH (1972) Nomenclature for physiologic races of Puccinia striiformis infecting wheat. Trans $\mathrm{Br} M y c o l$ Soc $58,475-480$

Joudrier P (1974) Bulletin des Variétés, Céréales, GEVES, INRA

Joudrier P (1974) Généalogie des variétés de blé tendre d'origine française Bull Anc Elèves Ec Fr Meun 264, 1-6

Labrum KE (1980) The location of Yr2 and Yr6 genes conferring resistance to yellow rust. Proc 5th European and Mediterranean Cereal Rusts Conference, 1980, Bari-Rome, Italy, 41-45

Lupton FGH, Macer RCF (1962) Inheritance of resistance to yellow rust (Puccinia glumarum Erickss and Henn) in seven varieties of wheat. Trans Br Mycol Soc 45, 21-45

Macer RCF (1972) The resistance of cereals to yellow rust and its exploitation by breeding. $\operatorname{Pr} R$ Soc London Ser B Biol Sci 181, 281-301

McIntosh RA (1983) A Catalogue of Gene Symbols for Wheat (1983 edn) Proc 6th Int Wheat Genetics Symp, Kyoto, Japan, 1983, 1197-1254

Mcintosh RA (1986) A catalogue of gene symbols for wheat: 1986 supplement Cereal Res Commun 14, 105-115

McNeal FH, Konzak CF, Smith EP, Tate WS, Russel TS (1971) A uniform system for recording and processing cereal research data. US Agric Res Serv 42, 34-121 
Priestley RH, Bayles RA (1980) Varietal diversification as a means of reducing the spread of cereal diseases in the United Kingdom. I Nat Inst Agric Bot 15, 205-214

Rapilly F (1976) Essai d'explication de l'épidémie de rouille jaune sur blé en 1975. Sel Fr 22, 47-52

Röbbelen G, Sharp EL (1978) Mode of inheritance, interaction and application of genes conditioning resistance to yellow rust. In: Advances in Plant Breeding (Horn W, ed) Parey, Berlin, Hannover, G Röbbelen Pflanzenzücht 9, 88 pp

Stubbs RW (1967) Influence of light intensity on the reactions of wheat and barley seedlings to Puccinia striiformis. Phytopathology 57, 615-619

Stubbs RW (1985) Stripe rust. In: The Cereal Rusts. (Roelfs AP, Bushnell WR, eds) Academic Press, Orlando, CA 2, 61-101

Taylor AJ, Smith GMB, Johnson R (1981) Race- specific genetic factors for resistance to Puccinia striiformis in wheat cultivars from the Plant Breeding Institute. Cereal Rusts Bull 9(2), 33-45

De Vallavieille-Pope C, Goyeau H, Pinard F, Vergnet C, Mille B (1988) Integrating varietal mixtures and fungicide treatments: preliminary studies of a strategy for controlling yellow rust of wheat. In: Integrated Crop Protection in Cereals. Proc Meeting, EC Experts' Group, Littlehampton, UK, 2527 November 1986, 199-207

Wolfe MS (1985) The current status and prospects of multiline cultivars and variety mixtures for disease resistance. Ann Rev Phytopathol 23, 251-273

Zadoks JC (1961) Yellow rust on wheat studies in epidemiology and physiologic specialization. Tijdschr Plantenziekten 67, 69-256

Zadoks JC (1971) System analysis and the dynamics of epidemics. Phytopathology 61, 600-610 